\title{
Hydrochemical and Geochemical Characteristics of Geothermal Water in Gedong Area of Guizhou Province
}

\section{Ban Wentao ${ }^{1 *}$ and Li Bo ${ }^{1,2}$}

${ }^{1}$ College of Resource and Environmental Engineering, Guizhou University, Guiyang, Guizhou 550000, PR China

${ }^{2}$ Key Laboratory of Karst Environment and Geohazard Prevention, Guizhou University, Guiyang, Guizhou 550000, PR China

\begin{abstract}
Geothermal energy is a green and renewable energy source. There are abundant geothermal resources in Gedong area of Guizhou Province, China. The Geothermal resources are controlled by regional structure. The shape of heat storage is zonal distribution. Inorder to know more about the characteristics of banded thermal reservoirs and provide reference for the development and utilization of banded thermal reservoirs in Qiandongnan area of Guizhou, on the basis of fully understanding the geothermal geological conditions in the Gedong area of Guizhou, the samples of geothermal fluid were collected and the hydrochemistry, hydrogen and oxygen isotopes of regional geothermal water were analyzed. The result shows that regional geothermal water circulation is very deep. The circulation depth of geothermal water is at least $1330 \mathrm{~m}$. Ground water is heated continuously by large geothermal flow during circulation and finally becomes geothermal water. The source of geothermal water supply is meteoric water and its lower limit of recharge height is $926 \mathrm{~m}$. The characteristics of hydrogen and oxygen isotopes of geothermal water in different geothermal wells (Springs) are different, and the main factor is elevation. The chemical composition of geothermal water is controlled by the surrounding rock of geothermal water, the dissolved specific mineral of geothermal water and the circulation of geothermal water are difference. Geothermal water in different geothermal wells (Springs) can be divided into two groups. The division is based on whether geothermal water reaches mineral equilibrium and whether it is mixed with shallow ground water.
\end{abstract}

Keywords: Hydrochemical type; Hydrgen-oxygen isotope analysis; Geothermal water; Circulation depth; China

\section{Introduction}

At present, energy shortage and environmental pollution have become one of the important problems that restrict the sustainable development of the whole world. Geothermal energy is a green, lowcarbon and recyclable renewable energy source [1]. The geothermal resources in Guizhou province are rich, but the exploration and exploitation level are low [2,3]. The Gedong area of Gui Zhou generally includes Taijiang, Jianhe, Leishan, cengong and Sansui areas. Today, there are 2 natural hot springs and 6 geothermal wells in this area (Figure 1). Since the 80s of last century, the Guizhou Institute of Geology and the Guizhou Institute of environmental science, respectively, the hot springs in Jianhe were investigated and studied. In 2009, the Guizhou Provincial Department of land and resources submitted the research manual on the exploration, exploitation and utilization of geothermal water resources in Jianhe, and planned the geothermal resources of Jianhe County. Although predecessors carried out some explorations and researches to the region of Jianhe, Leishan geothermal resources [1,4-6], it has not systematically studied the hydrogeochemistry and thermal storage temperature in the whole of Gedong area, and this researches in this area has played an important role in dividing the geothermal system types and evaluating the potential of geothermal resources [1,7-9]. Therefore, this paper takes geothermal water as an object of study. Based on the principal analytic hierarchy process, the hydrochemical test data of hot water in inland area were analyzed. And based on geochemical theory, the characteristics of $\mathrm{H}$ and $\mathrm{O}$ isotopic compositions of fluids are analyzed. Geochemical characteristics and evolutive characteristics of thermal fluids in the interior of the area are discussed. The water rock equilibrium state of the thermal anomaly points in the Gedong area is determined by using the Na$\mathrm{K}-\mathrm{Mg}$ triangle diagram and the multi mineral equilibrium method. To Select a reasonable calculation of leather geothermometer heat reservoir temperature in Gedong area, the purpose is to understand the formation mechanism of geothermal resources in the Gedongt area and to provide a new reference for the exploitation and utilization of geothermal resources in this area.

\section{General Situation of the Study Area}

Located in the east slope of Guizhou plateau, the Gedong area is adjacent to the fold belt of the southwest and the north to the Yangtze quasi platform [10]. The terrain is high in the southeast and low in the north and West. The landforms are erosion and peak cluster depressions. The direction of the mountain stretch is basically the same as that of the structure, and most of them are NNE trending. In the region, the strata of Jianhe, Taijiang and Leishan regions are mainly blastopsammite of Qingshuijiang group (Qbq), Wuye group (Qbw), Fanzhao (Qbf) group and Jalu group $(\mathrm{Qbj})$ of Qingbaikouan system. The upper part of the regional stratigraphic Cengong is the Cambrian Shilengshui group dolomite $\left(\epsilon_{2} \mathrm{~s}\right)$, Qingxudong group limestone $\left(\epsilon_{1} \mathrm{q}\right)$. The underpart of regional strata is the Cambrian Palang group blastopsammite $\left(\epsilon_{1} p\right)$ and Qingshuijiang group (Qbq) of Qingbaikouan. The structures in the area are mainly NNE trending folds and faults, respectively Sansui syncline, Donglong syncline, Leishan syncline, Chong Suoxi anticline, Gedong fault, Shidongkou fault and Wen Shao fault (Figure 1).

The fault of Gedong, Shidongkou and Wen Shao is neoid active faults. The geothermal wells and hot spring of Jianhe and Taijiang,

*Corresponding author: Ban Wentao, College of Resource and Environmental Engineering, Guizhou University, Guiyang, Guizhou 550000, China, Tel: 8685183627738; E-mail: 1927552890@qq.com

Received June 24, 2017; Accepted July 05, 2017; Published July 10, 2017

Citation: Wentao B, Bo L (2017) Hydrochemical and Geochemical Characteristics of Geothermal Water in Gedong Area of Guizhou Province. J Environ Anal Toxicol 7: 488. doi: 10.4172/2161-0525.1000488

Copyright: @ 2017 Wentao B, et al. This is an open-access article distributed under the terms of the Creative Commons Attribution License, which permits unrestricted use, distribution, and reproduction in any medium, provided the original author and source are credited. 
Citation: Wentao B, Bo L (2017) Hydrochemical and Geochemical Characteristics of Geothermal Water in Gedong Area of Guizhou Province. J Environ Anal Toxicol 7: 488. doi: 10.4172/2161-0525.1000488

Page 2 of 6

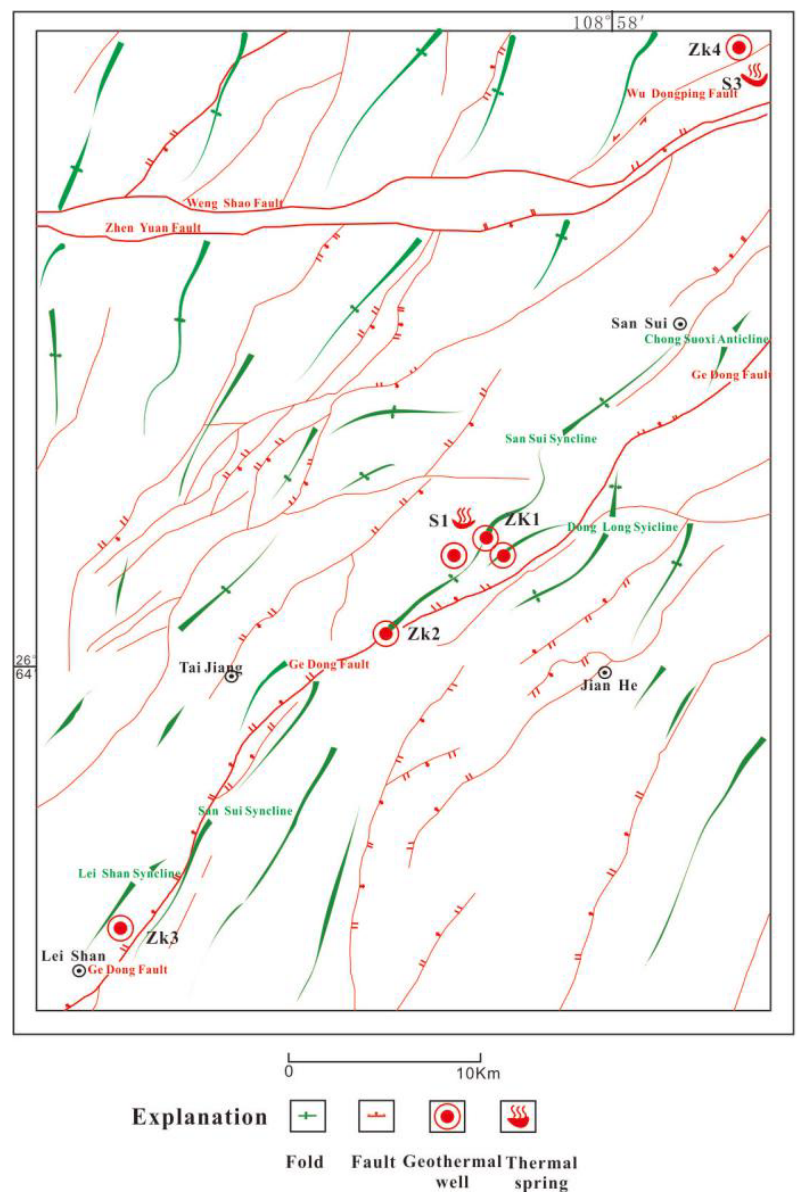

Figure 1: The geological map of region.

Leishan area is located in between the Gedong fault and its secondary faults and folds. They are controlled by the Gedong fault and the shape of the thermal reservoirs is zonal distribution. The geothermal wells and hot spring of Cenggong are controlled by Wudongping fault, WenShao fault and Shidongkou fault. The shape of the thermal reservoirs in this area is zonal distribution (Table 1).

The regional geothermal wells and hot springs are located in the upper wall of the neoid active faults. The neoid active faults and their secondary faults are the main runoff paths of geothermal water. The cyclic geothermal water moves upward along the upper wall of the fault. The relative thermal conductivity between strata and strata forms a relative heat insulating layer.

\section{Sampling and Testing}

Sampling of water chemistry and isotope samples was carried out in the region in May 2014. The samples of water quality analysis are collected with $2.5 \mathrm{~L}$ plastic bottle. Samples of hydrogen and oxygen isotopes were collected in $500 \mathrm{~mL}$ plastic bottles. Before collecting, clean the bottle of sample 3 times with distilled water and fill the sample bottle with water and then seal the bottle with wax. Finally, the bottles are attached to labels. And the sample will be sent to the Guizhou geological and mineral Center Laboratory for testing immediately. The delivery time of sample is not more than 48 hours. The accuracy of analysis of hydrogen and oxygen isotopes is $\pm 1.0 \%$ and $\pm 0.2 \%$.

\section{Interpretation of Results and Discussion}

\section{Hydrochemical characteristics}

According to the analysis results of regional water samples, Piper diagram is made (Figure 2). As you can see in Figure 2, the data points are all concentrated in the same range. The chemical type of regional geothermal water is $\mathrm{HCO}_{3}-\mathrm{Na}^{+}$. Its TDS is less than $1 \mathrm{~g} / \mathrm{L}$, belong to fresh water. Combined with regional hydrogeological conditions, chemical characteristics of geothermal water were analyzed based on principal component analysis. Principal component analysis is different from correlation analysis [2]. The correlation analysis considers only the correlation between the two variables. However principal component analysis takes into account the relationship among all the original variables, the independent factors of principal component can be extracted after transformation, and the main influencing factors can be analyzed according to the principal component factor.

According to principal component analysis, regional geothermal water is mainly affected by 3 factors, the main components of F1, F2, F3 of the contribution rate were $53.76 \%, 23.93 \%, 18.52 \%$, and the cumulative contribution rate was $96.22 \%$. That shows that the first, the second and the third principal component represents the amount of information provided by the original $96.22 \%$ (Table 2 ). The principal component analysis of the 11 variables in the region is shown in Table 3. The principal component analysis diagram, consisting of F1, F2 and F3, is shown in Figure 3. By the load graph of each variable on the principal component axis (Figure 3), the $\mathrm{K}^{+}, \mathrm{Na}^{+}, \mathrm{Ca}^{2+}, \mathrm{Mg}^{2+}, \mathrm{HCO}_{3}$. and $\mathrm{SiO}_{2}$ can be found to have higher load on the $\mathrm{F} 1$, and the absolute value range is $0.72-0.95$. Taking into account the regional stratigraphic lithology, mainly for the Qingbakou system's blastopsammite and Cambrian sandstone, its main components are feldspar and quartz. When the system contains a certain amount of $\mathrm{CO}_{2}$, the water reacts with feldspar minerals (type 1 is albite, potash feldspar and anorthite are similar to albite), and then the $\mathrm{HCO}_{3}-\mathrm{Na}$ type of water is formed. The first principal component $\mathrm{F} 1$ reflects the close relationship between the chemical composition of geothermal water and the surrounding rocks in this area. F1 accounted for $53.76 \%$ of the contribution, and the occurrence of geothermal water in sandstone and blastopsammite plays an important role in hydrochemical composition of geothermal water. The $\mathrm{Na}^{+}$content in geothermal water is high, which is presumed to be rich in albite minerals in the geothermal water filter. The solubility of this mineral is low, so the content of $\mathrm{Na}^{+}$in geothermal water is high, but the salinity is not high.

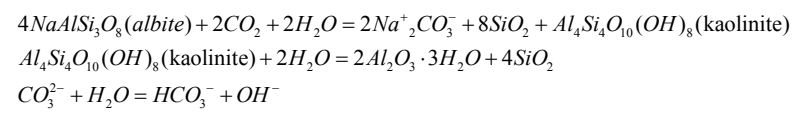

In Figure 3, $\mathrm{F}^{-}, \mathrm{SO}_{4}^{2-}$ and $\mathrm{pH}$ have higher loads on the $\mathrm{F} 2$, and their absolute range is $0.6-0.86$. The $\mathrm{F}^{-}$in geothermal water is mainly derived from the dissolved fluorine minerals (such as fluorite). The $\mathrm{SO}_{4}^{2-}$ is mainly derived from dissolved sulfate minerals (such as anhydrite). The second principal component F2 reflects the influence of specific mineral leaching by geothermal water on the chemical composition of geothermal water.

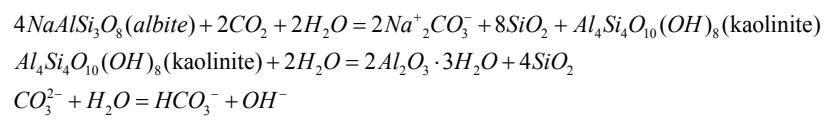

As shown in Figure 3, $\mathrm{Cl}^{-}$and water temperature T have higher load 
Citation: Wentao B, Bo L (2017) Hydrochemical and Geochemical Characteristics of Geothermal Water in Gedong Area of Guizhou Province. J Environ Anal Toxicol 7: 488. doi: 10.4172/2161-0525.1000488

Page 3 of 6

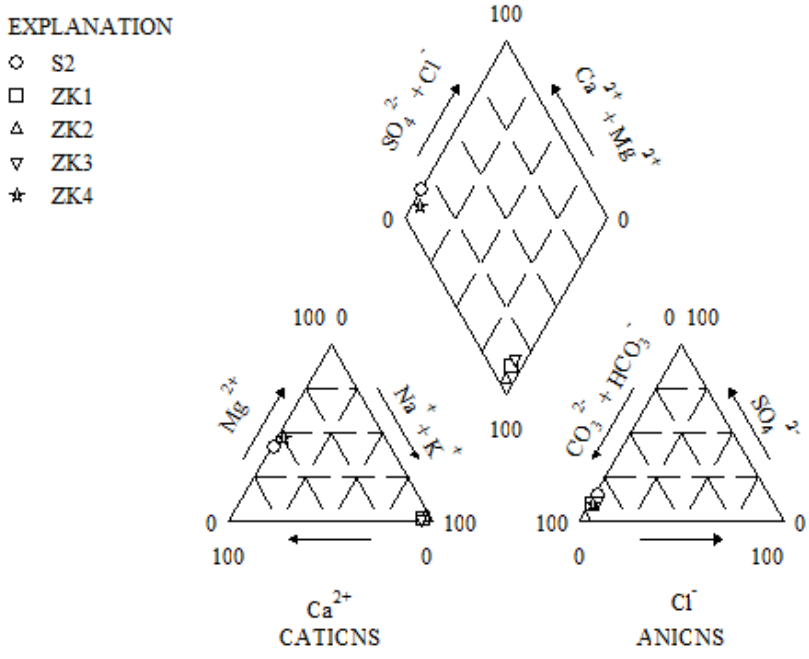

Figure 2: The Piper diagram of water samples.

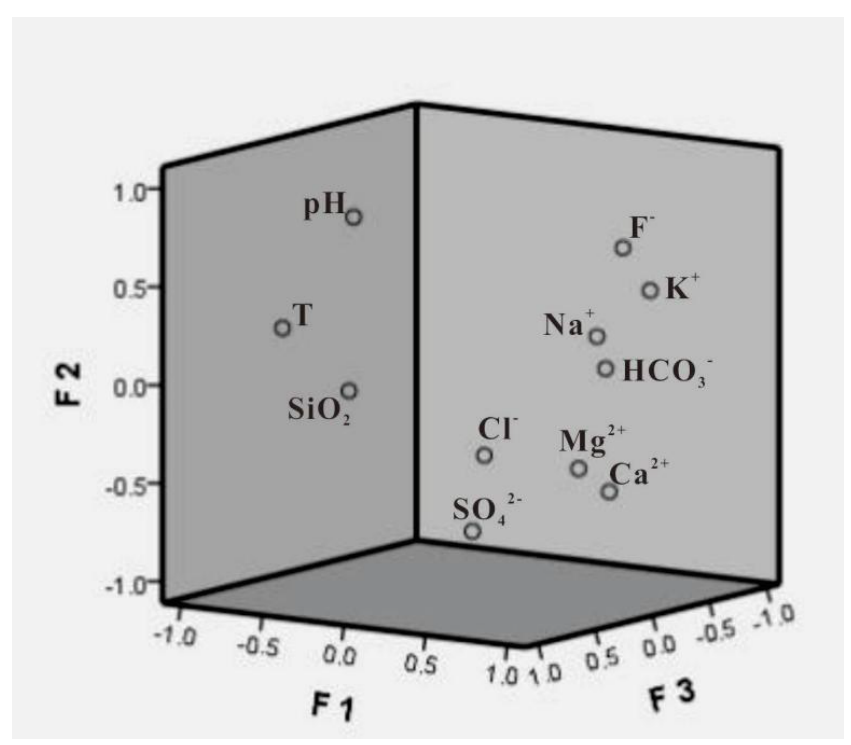

Figure 3: Principal component analysis discriminant plane graph. on $\mathrm{F} 3$, the range of absolute value is $0.63-0.75$, and the $\mathrm{K}^{+}$has moderate load on F3, and the absolute value is 0.53 . The consideration is mainly due to geothermal water leaching of chloride from rocks (such as potassium salts). Because of the natural water chloride dissolved easily, the formation of a stable $\mathrm{Cl}^{-}, \mathrm{Cl}^{-}$easy transfer, so only the hot water into the deep water stagnant zone, possible leaching of chloride. The F3 of principal components reflects the influence of regional geothermal water cycle on the chemical composition of geothermal water.

Due to the regional geothermal water, chemical types are $\mathrm{HCO}_{3}$ $\mathrm{Na}$, in order to better distinguish between different wells (Springs) the chemical characteristics of water, here using the method of cluster analysis to divide the area of geothermal water, the results shown in Figure 4. As you can see from Figure 4, when the samples are divided into two classes, one is ZK1, ZK3 and ZK4, and the other is ZK2 and S2. The difference between these two categories is mainly to consider whether geothermal water is chemically balanced and mixed with shallow subsurface water. From the $\mathrm{Na}-\mathrm{K}-\mathrm{Mg}$ triangle diagram (Figure 5), the ZK2 and S2 samples are in a partial equilibrium area, which indicates that some of these water samples may have partial chemical equilibrium and may be affected by mixing of shallow groundwater. The samples of ZK1, ZK3 and ZK4 are in immature water areas, indicating that such water samples may not yet reach chemical equilibrium. The $\mathrm{SiO}_{2}$ content of ZK2 and S2 water samples is lower than that of ZK1, $\mathrm{ZK} 3$ and $\mathrm{ZK} 4$ water samples. The possible explanation is that $\mathrm{ZK} 2$ and S2 water samples are mixed by shallow groundwater.

As you can see from Figure 5, the water sample is in partially balanced area and immature area, and that means not using cationic scale, but the use of $\mathrm{SiO}_{2}$ scale [8]. Phreeqc software is used to calculate the saturation index of heat storage minerals at different temperatures, and to estimate the thermal storage temperature by using multi mineral balance method [11]. Regional lithology is mainly blastopsammite and sandstone, consisting chiefly of feldspar and quartz, change in hydrothermal alteration, occurrence of chalcedony. Therefore, the calculation of selected quartz, chalcedony, feldspar, fluorite and anhydrite minerals as reference, simulation results shown in Figure 6 (listed only ZK1, the rest does the same treatment). After calculation, regional water saturation index of quartz, chalcedony closest to 0 (Table 4 ), the content of $\mathrm{SiO}_{2}$ is mainly controlled by quartz and chalcedony, so using quartz and chalcedony is estimated heat storage temperature range (Table 4). The differences between the calculated temperature and geothermometer multi mineral equilibrium temperature is mainly owing to the mixing water and the groundwater. The actual logging

\begin{tabular}{|c|c|c|c|c|}
\hline Number & Tectonic position & Well depth/m & Water temperature of Wellhead $/{ }^{\circ} \mathrm{C}$ & Flow $/ m^{3} \cdot d^{-1}$ \\
\hline Thermal spring S1 of Jianhe & Between Chongsuoxi anticline and Gedong fault & - & 48 & 1797.75 \\
\hline Thermal spring S2 of Cengong & $\begin{array}{c}\text { Among Wu Dongping fault, Wen Shaosfault and } \\
\text { Shi Dongkou fault }\end{array}$ & - & 28 & 1728.6 \\
\hline Geothermal well ZK1 of Janhe & $\begin{array}{l}\text { Among Ge Dong fault, Chongsuoxi anticline and } \\
\text { San Sui syncline }\end{array}$ & 1750 & 38 & 1800.46 \\
\hline Geothermal well ZK2 of Taijiang & Between San Sui syncline and Gedong fault & 1618 & 40 & 841.85 \\
\hline Geothermal well ZK3 of Leishan & $\begin{array}{l}\text { Among Ge Dong fault, Leishan syncline and San } \\
\text { Sui syncline }\end{array}$ & 2300 & 45 & 1030.95 \\
\hline Geothermal well ZK4 of Cengong & $\begin{array}{c}\text { Among Wu Dongping fault, Wen Shaos fault and } \\
\text { Shi Dongkou fault }\end{array}$ & 802 & 46 & 6998 \\
\hline
\end{tabular}

Table 1: Geothermal well location information. 
Citation: Wentao B, Bo L (2017) Hydrochemical and Geochemical Characteristics of Geothermal Water in Gedong Area of Guizhou Province. J Environ Anal Toxicol 7: 488. doi: 10.4172/2161-0525.1000488

Page 4 of 6

\begin{tabular}{|c|c|c|c|c|c|c|c|c|c|c|c|c|c|}
\hline \multirow{2}{*}{ Number } & \multicolumn{9}{|c|}{$\rho E /(m g / L)$} & \multirow{2}{*}{$\begin{array}{c}\text { Temperature of } \\
\text { waterT } /{ }^{\circ} \mathrm{C}\end{array}$} & \multirow[t]{2}{*}{ pH } & \multirow[t]{2}{*}{$\delta D$} & \multirow[t]{2}{*}{$\delta^{18} O$} \\
\hline & $\mathbf{K}^{+}$ & $\mathrm{Na}^{+}$ & $\mathrm{Ca}^{2+}$ & $\mathbf{M g}^{\mathbf{2 +}}$ & $\mathrm{Cl}^{-}$ & $\mathrm{SO}_{4}{ }^{2-}$ & $\mathrm{HCO}_{3}^{-}$ & $\mathrm{SiO}_{2}$ & $\mathrm{~F}^{-}$ & & & & \\
\hline S2 & 4.61 & 211.06 & 5.73 & 1.74 & 2.65 & 12.05 & 610.81 & 20.10 & 7.64 & 28.00 & 8.09 & -54.30 & -8.19 \\
\hline ZK1 & 1.88 & 85.10 & 2.90 & 0.75 & 1.67 & 18.19 & 223.91 & 46.52 & 1.68 & 38.00 & 8.00 & -59.70 & -8.83 \\
\hline ZK2 & 2.21 & 239.40 & 5.32 & 2.73 & 7.14 & 12.89 & 708.54 & 19.99 & 1.28 & 40.00 & 8.07 & -63.20 & -9.26 \\
\hline ZK3 & 0.84 & 46.39 & 1.83 & 0.37 & 2.45 & 12.18 & 119.65 & 38.57 & 0.35 & 47.00 & 8.46 & -69.20 & -10.03 \\
\hline ZK4 & 3.18 & 200.09 & 0.0082 & 0.50 & 2.41 & 10.06 & 467.27 & 33.87 & 5.68 & 46.00 & 8.54 & -57.50 & -8.64 \\
\hline
\end{tabular}

Table 2: Chemical and isotopic compositions of samples.

\begin{tabular}{|c|c|c|c|c|c|c|c|}
\hline \multicolumn{4}{|c|}{ Principal component total variance interpretation } & \multicolumn{4}{|c|}{ The loading of Variable } \\
\hline Principal component & Characteristic value & Percentage variance & Cumulation \% & & F1 & $\mathbf{F 2}$ & F3 \\
\hline 1 & 5.914 & 53.761 & 53.761 & $\mathrm{~K}^{+}$ & 0.727 & 0.429 & -0.53 \\
\hline 2 & 2.632 & 23.931 & 77.693 & $\mathrm{Na}^{+}$ & 0.885 & 0.312 & 0.162 \\
\hline 3 & 2.038 & 18.527 & 96.22 & $\mathrm{Ca}^{2+}$ & 0.788 & -0.524 & -0.086 \\
\hline 4 & 0.416 & 3.78 & 100 & $\mathrm{Mg}^{2+}$ & 0.884 & -0.339 & 0.321 \\
\hline 5 & $3.90 \mathrm{E}-16$ & $3.55 \mathrm{E}-15$ & 100 & $\mathrm{Cl}^{-}$ & 0.61 & -0.236 & 0.754 \\
\hline 6 & $1.99 \mathrm{E}-16$ & $1.81 \mathrm{E}-15$ & 100 & $\mathrm{SO}_{4}{ }^{2-}$ & -0.234 & -0.867 & -0.348 \\
\hline 7 & $-2.02 E-17$ & $-1.83 E-16$ & 100 & $\mathrm{HCO}_{3}^{-}$ & 0.951 & 0.158 & 0.18 \\
\hline 8 & $-1.14 \mathrm{E}-16$ & $-1.03 E-15$ & 100 & $\mathrm{~F}^{-}$ & 0.518 & 0.618 & -0.59 \\
\hline 9 & $-3.53 E-16$ & $-3.21 E-15$ & 100 & $\mathrm{SiO}_{2}$ & -0.915 & -0.206 & -0.241 \\
\hline 10 & $-6.53 E-16$ & $-5.93 E-15$ & 100 & $\mathrm{pH}$ & -0.511 & 0.798 & 0.297 \\
\hline 11 & $-1.23 E-15$ & $-1.12 \mathrm{E}-14$ & 100 & $T$ & -0.708 & 0.262 & 0.636 \\
\hline
\end{tabular}

Table 3: Principal component total variance interpretation and analysis result.

\begin{tabular}{|c|c|c|c|c|c|c|c|c|}
\hline \multirow{2}{*}{ Number } & \multicolumn{2}{|c|}{ Saturation index SI } & \multirow[t]{2}{*}{$\begin{array}{c}\text { Thermometric } \\
\text { scale of quartz } 1 /{ }^{\circ} \mathrm{C}\end{array}$} & \multirow[t]{2}{*}{$\begin{array}{l}\text { Thermometric scale } \\
\text { of quartz } 2 /^{\circ} \mathrm{C}\end{array}$} & \multirow{2}{*}{$\begin{array}{c}\text { Thermometric } \\
\text { scale of } \\
\text { Chalcedony } /{ }^{\circ} \mathrm{C}\end{array}$} & \multirow{2}{*}{$\begin{array}{c}\text { Multi } \\
\text { mineral } \\
\text { balance } \\
\text { method } /{ }^{\circ} \mathrm{C}\end{array}$} & \multirow[t]{2}{*}{$\begin{array}{l}\text { Wellhead fluid } \\
\text { temperature } /{ }^{\circ} \mathrm{C}\end{array}$} & \multirow{2}{*}{$\begin{array}{c}\text { Measured } \\
\text { bottom hole } \\
\text { temperature } /{ }^{\circ} \mathrm{C}\end{array}$} \\
\hline & quartz & Chalcedony & & & & & & \\
\hline ZK1 & 0.0041 & 0.0073 & 98.48 & 99.67 & 68.3 & 86 & 38 & - \\
\hline ZK2 & 0.0081 & 0.0074 & 63.42 & 68.93 & 31.35 & 89 & 40 & 62.4 \\
\hline ZK3 & 0.0059 & 0.0057 & 90.08 & 92.39 & 59.35 & 93 & 47 & 76.5 \\
\hline ZK4 & 0.0106 & 0.0046 & 84.48 & 87.50 & 53.41 & 85 & 46 & 65.2 \\
\hline S2 & 0.0081 & 0.0059 & 63.63 & 69.12 & 31.56 & 52 & 28 & - \\
\hline
\end{tabular}

Table 4: The calculation result of Temperature scale and SI.

temperature is lower than the multi mineral equilibrium temperature, and the reason is that the actual geological conditions are very complex. The distribution of thermal reservoirs controlled by structure is more complex. When choosing drilling location, it often deviates from the thermal reservoir, so that the actual logging temperature is often lower than the actual heat storage temperature [8].

The equilibrium temperature is regarded as the heat storage temperature, and the geothermal water circulation depth is estimated according to formula 2. According to the ground temperature logging data, the average geothermal gradient of the region is $2.83^{\circ} \mathrm{C} / 100$ $\mathrm{m}$, and the depth of the normal temperature is $\mathrm{h}$, taking $30 \mathrm{~m}$. The temperature at normal temperature of $\mathrm{ZK} 1, \mathrm{ZK} 2, \mathrm{ZK} 3, \mathrm{ZK} 4$ and $\mathrm{S} 2$ is $17.5,16.8,16.7,15.9,15.2$, respectively. It is estimated that the depth of hot water circulation in ZK1, ZK2 and ZK3 reaches $2450 \mathrm{~m}, 2581 \mathrm{~m}$, $2726 \mathrm{~m}, 2471 \mathrm{~m}$ and $1330 \mathrm{~m}$.

$$
H=\left(t_{1}-t_{2}\right) / G+h
$$

The $\mathrm{H}$ is the geothermal water circulation depth $(\mathrm{m}) ; \mathrm{t}_{1}$ is the heat storage temperature $(\mathrm{m}) ; \mathrm{t}_{2}$ is the temperature at normal temperature $\left({ }^{\circ} \mathrm{C}\right) ; \mathrm{G}$ is the geothermal gradient $\left({ }^{\circ} \mathrm{C} / 100 \mathrm{~m}\right)$; $\mathrm{h}$ is the depth of normal temperature $(\mathrm{m})$.

\section{Isotope geochemical characteristics}

The regional hydrogen oxygen isotope is divided into $\delta \mathrm{D}-\delta^{18} \mathrm{O}$
(Figure 7). The point of projection is located on the Chinese meteoric water line [12], indicating that geothermal water comes from meteoric water supply. At the same time, to the right from the Guiyang meteoric water line [13] this may be due to the regional and Guiyang latitude, elevation, temperature and rainfall differences.

Because the content of $\mathrm{H}$ in most rock forming minerals is relatively low, the underground hot water is almost not exchanged with the $\mathrm{H}$ in the surrounding rock. When $\delta^{18} \mathrm{O}$ is defined as a measure of isotopic exchange, $d$-excess $=\delta \mathrm{D}-8 \delta^{18} \mathrm{O}$ is often chosen [14]. The results show that ZK1, ZK2, ZK3, ZK4 and S2 are $10.94 \%, 10.88 \% 11.04 \%$, $11.62 \%$ and $11.22 \%$. The global meteoric water line $\delta^{18} \mathrm{O}-\delta \mathrm{D}$, which was given by Craig in 1961 shows that the d-excess value of atmospheric precipitation is $10 \%$, and the regional geothermal water d-excess is near it. Therefore, the degree of isotopic exchange between regional geothermal water and surrounding rock is low, and the water rock interaction environment is not closed. This is because the fault zone is caused by many pores and fissures, and this is obviously different from the high temperature reservoir $[15,16]$. Therefore, geothermal water originates from meteoric water and is in the medium and low temperature thermal reservoir.

Due to the difference of latitude and longitude, temperature and rainfall between ZK1, ZK2, ZK3, ZK4 and S2, the elevation of hydrogen and oxygen isotopes in geothermal wells should be dominated by 
Citation: Wentao B, Bo L (2017) Hydrochemical and Geochemical Characteristics of Geothermal Water in Gedong Area of Guizhou Province. J Environ Anal Toxicol 7: 488. doi: 10.4172/2161-0525.1000488

Page 5 of 6

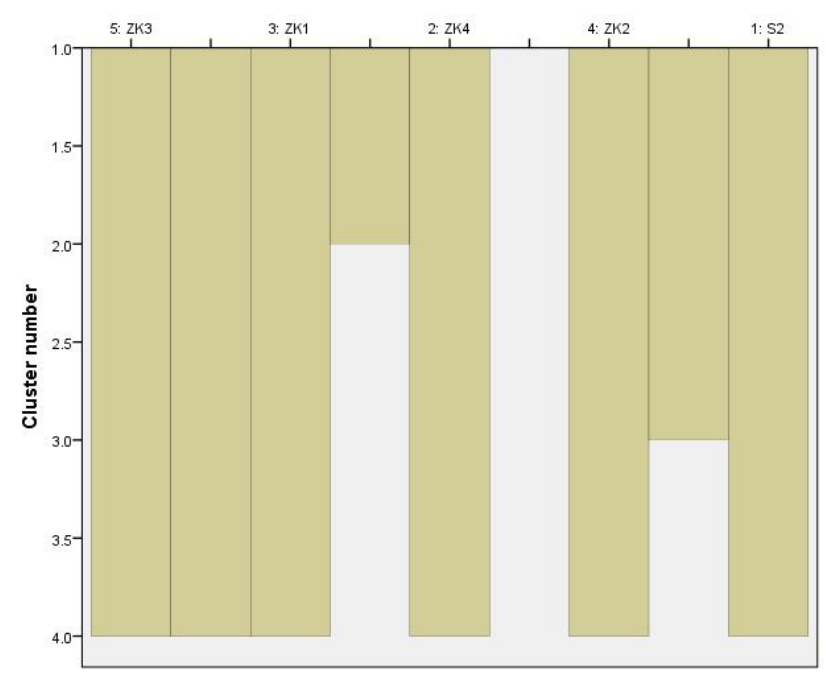

Figure 4: The result of cluster analysis.

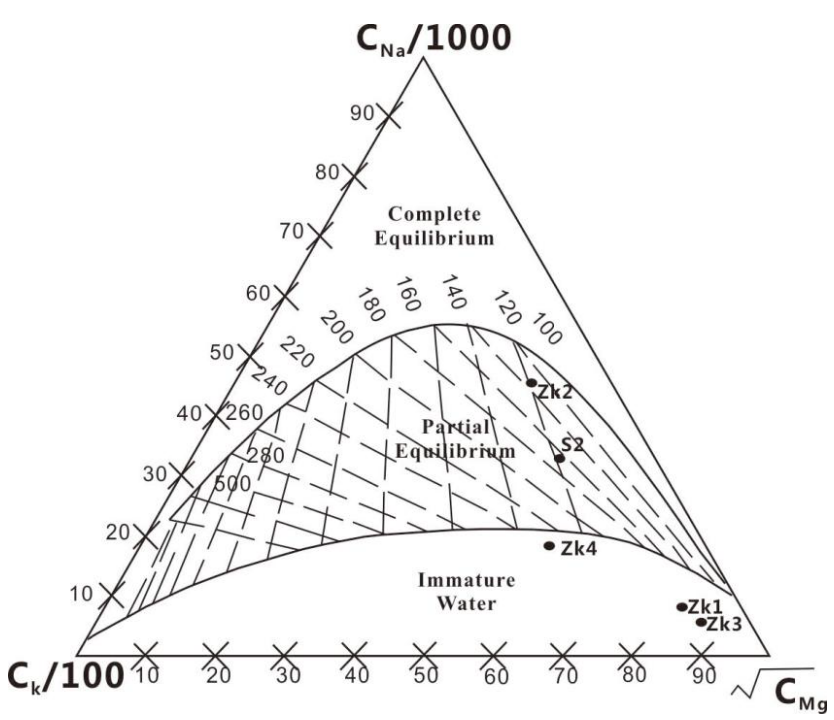

Figure 5: Na-K-Mg Triangular diagram map.

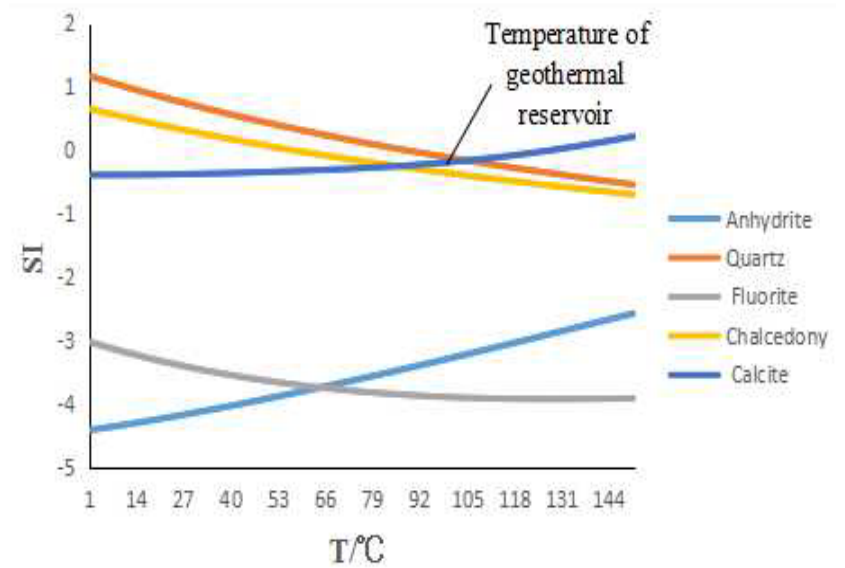

Figure 6: Relation between SI and T of ZK1 geothermal water.

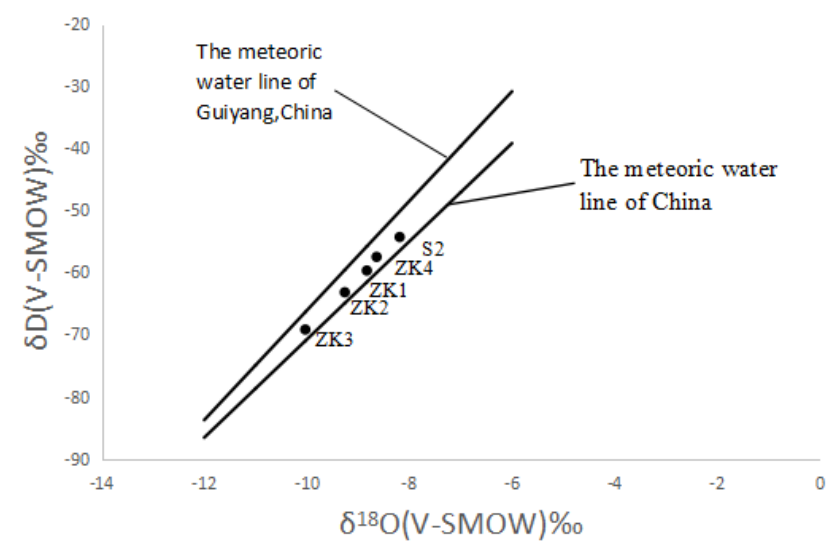

Figure 7: Relation between $\delta D$ and $\delta 180$ of water samples.

elevation effect. According to the estimation formula of elevation effect and Sichuan Tibet isotope elevation effect (delta $\mathrm{D}=-0.026 \mathrm{H}-30.2)$ in the study area [17], the supply elevation of ZK1, ZK2, ZK3, ZK4, S2 was estimated by $1134 \mathrm{~m}, 1269 \mathrm{~m}, 1500 \mathrm{~m}, 1050 \mathrm{~m}$ and $926 \mathrm{~m}$ respectively.

\section{Heat source analysis}

Since the Xuefeng movement, the region is in a stable land mass tectonic environment. Since the Cenozoic, there is no magmatic intrusion and volcanism. The heat reservoir temperature is lower than $100^{\circ} \mathrm{C}$, a medium low temperature storage, the lack of regional water related to volcano, magmatism in a large number of $\mathrm{CO}_{2}, \mathrm{H}_{2} \mathrm{~S}$ and other ingredients, also did not appear obvious drift of oxygen isotope, nonintrusive granite regional stratigraphic distribution, lack of material basis radioactive source. Therefore, the regional geothermal water does not have magmatic and radioactive heat source conditions.

Region is located in the Wuling Mountain and northeast of Guangxi SN to the gradient zone of gravity anomaly [3]. It is a primary fault (deep fracture) in the east of Guizhou. The value of geothermal flow is abnormally high, and the value distribution is mainly located in the suture boundary of the plate boundary and the deep fault active belt [18]. At the same time, the area is located in a relatively shallow location of Moho depth [19-21]. Geothermal water is formed in the process of deep circulation, under the larger value of terrestrial heat flow, which is heated by surrounding rock. Regional faults control the distribution of geothermal resources.

\section{Conclusions}

The chemical type of regional geothermal water is $\mathrm{HCO}_{3}-\mathrm{Na}$, the chemical component of water is mainly affected by 3 factors. The first factor is the stratum of sandstone and blastopsammit; the second factor is the geothermal water leaching of certain minerals; the third factor is the deep circulation of geothermal water. Further, the division of regional geothermal water shows that regional geothermal water can be divided into two main types, whether or not the hot water in the main base has reached the balance of chemical reaction of some mineral and the mixture of shallow ground water and ground water. The heat storage temperature is about $52^{\circ} \mathrm{C}-93^{\circ} \mathrm{C}$, and the geothermal water circulation depth is about $1330 \mathrm{~m}-2726 \mathrm{~m}$. The supply of geothermal water is atmospheric water, the interaction between water and rock is weak, and the recharge elevation is about $926 \mathrm{~m}-1500 \mathrm{~m}$. Geothermal energy in the region is not magmatic and radioactive heat sources, mainly by regional geothermal flow heating. 
Citation: Wentao B, Bo L (2017) Hydrochemical and Geochemical Characteristics of Geothermal Water in Gedong Area of Guizhou Province. J Environ Anal Toxicol 7: 488. doi: 10.4172/2161-0525.1000488

\section{References}

1. Meng F, Yang $Y$ (2015) Hydrochemical characteristics and formation mechanism of Jianhe hot spring in Guizhou. China Mining Magazine 24: 58-77.

2. Liu LH, Su LC, Wang MM, Dong GM, Tao YF (2009) Application of principal component analysis to identify the hydrodynamic and hydrochemistry characteristics in karst mutlti-media system. Geotechnical Investigation and Surveying 6: 43-46.

3. Wang Y, Xun Z, Yuan Y, Yang CH, Zhou HY (2007) Application of geothermometers to calculation of temperature of geothermal reservoirs. Geoscince 21: 605-612

4. Xin OC (2008) Analysis on the formation of Jianhe hot Springs in Guizhou province. Guizhou Geology 25: 225-227.

5. Zhao Y, Zhong YF (2014) Construction Technology of CK1 Geothermal Exploration Well in Leishan County, Guizhou Province. Prospecting Engineering 41: 32-40.

6. Duan QS, Qing SX, Meng FT, Dong CZ (2015) Study on occurrence regularity of geothermal water in metamorphic rock area of eastern Guizhou. Groundwater 37: $37-39$

7. Liang W, Xiu-hong L, Ying-wen Z, Gong-hui L, Hua-hua L (2007) Distribution characteristics of gravity anomaly with a scale of 1 to 200,000 and new information exposed on regional geologic structure in Guizhou. Guizhou Geology 24: 64-67.

8. Lang XJ, Wen-jing L, Zhi-ming L, Lin-xiao X, Wang GL (2016) Hydrochemical characteristic of geothermal water in Guide basin. Earth Science 41: 17231734

9. Li-zhong $\mathrm{Y}$, Tao $\mathrm{H}$, Yu-long $\mathrm{H}$ (2008) Theory and application of seepage - stress - temperature coupling in fractured rock mass. Chendu: Southwest Jiaotong University Press, pp: 1-61.

10. Zhang SC, Chen LA (1998) Guizhou hot mineral water. Gui Yang: Guizhou Science and Technology Press, pp: 1-86.
11. Xin-Chen L, Zhi-yuan M, Xue-lian Z, Sen G, Meng Y, et al. (2016) Genetic model of the Dongda geothermal field in Guanzhong basin,Shanxi province. Geology in China 43: 2082-2091.

12. Shu-hui Z, Fa-gao H, Bao-lin N (1983) Study on Hydrogen and Oxygen Isotopes of Atmospheric Precipitation in China. Chinese Science Bulletin 28: 801-886.

13. Lei Z, Tao F, Huan G (2014) Sources and stable isotope characteristics of precipitation in southwest of China. Yunnan Geographic Environment Research 26: 61-67.

14. Qiong X (2012) Water-rock interaction and genesis of thermal groundwater in carbonate reservoir in Chongqing. Chongqing: Southwest University.

15. Zhi YM, Xin-gang W, Yan S, Juan Y (2008) Oxygen and hydrogen isotope exchange and its controlling factors in subsurface geothermal waters in the central Guanzhong basin, Shaanxi, China. Geological Bulletin of China 27 888-894.

16. De-u G, Zhong-he P, Quan-jiu W, Xian-Fang S (2011) Isotope Hydrology. Beijing: Science Press, China, pp: 576-588.

17. Jinshen Y, Hongbin Z, Fuji Y (1984) Oxygen and Hydrogen Isotopic Compositions of Meteoric Waters in the Eastern Part of Xizang. Geochemistry 3: 93-101.

18. Yu-song Y, Yong-shen M, Shen-biao H, Tong-lou G, Xiao-yue F (2006) Present-day geothermal characteristics in South China. Chinese J Geophys 49: $1118-1126$

19. Wu KB, Zeng GQ, Chen GX, Yang KG (2016) Deep structural features of Guizhou revealed by bouguer gravity anomaly. Geological Science and Technology Information 35: 190-199.

20. Zhiyuan M, Jun Y, Qing L, Xin-Gang W, Feng L, et al. (2008) Environmenta isotope distribution and hydrologic geologic sense of guanzhong basin geothermal water. Journal of Earth Science an Environment 30: 396-401.

21. Barak A, Bear J (1981) Flow at high reynolds numbers through anisotropic porous media. Advances in Water Resources 4: 54-67. 